
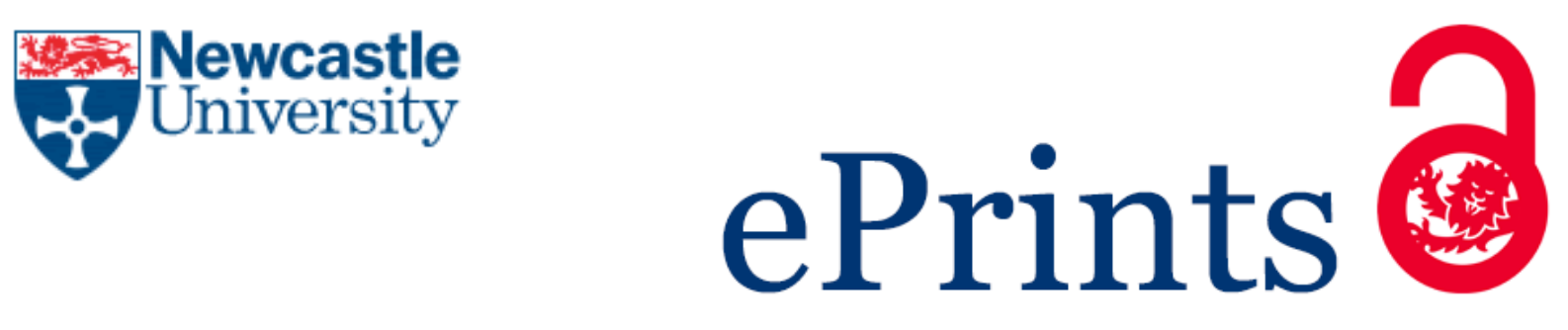

Benwell MC. From the banal to the blatant: expressions of nationalism in secondary schools in Argentina and the Falkland Islands. Geoforum 2014, 52, 51-60.

\title{
Copyright:
}

(C) 2013. This manuscript version is made available under the CC-BY-NC-ND 4.0 license

DOI link to article:

http://dx.doi.org/10.1016/i.geoforum.2013.12.006

Date deposited:

$17 / 08 / 2015$

Embargo release date:

14 January 2016

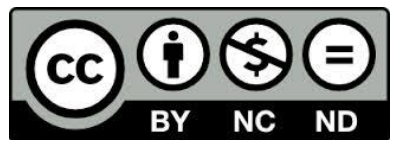

This work is licensed under a

Creative Commons Attribution-NonCommercial-NoDerivatives 4.0 International licence 


\section{From the banal to the blatant: expressions of nationalism in secondary schools in Argentina and the}

\section{Falkland Islands ${ }^{1}$}

\subsection{Introduction}

The concept of banal nationalism first coined by Billig (1995) was influential in drawing attention to expressions of nationhood which had hitherto gone unnoticed or unremarked upon in what he terms "established nations". Interest in nationalism had previously been limited to 'hotter' or exceptional forms of nationalist expression occurring elsewhere, apparent in, for instance, the struggles of separatist movements to form new nations. Billig's (1995: 38) work showed that "national identity in established nations is remembered because it is embedded in the routines of life, which constantly remind, or 'flag', nationhood". While several shortfalls with Billig's thesis have been subsequently identified and debated (author, 2011; Billig, 2009; Jones and Fowler, 2007; Jones and Merriman, 2009), there has been less critical discussion about the appropriateness of the term banal and what its influential theorisation has meant for the focus of subsequent research into daily reproductions of nationalism. Recent research has tended to highlight the potential problems with the generalised application of the term banal when considering nationalism and its reception, showing that exemplars of 'banal nationalism' are rarely received in uniform ways and that their consumption should be understood and situated within everyday, localised contexts (Agnew, 2004; author, 2011; Jones and Merrimen, 2009; Jones and Desforges, 2003; Sabhlok, 2010).

This paper does not contest these critiques concerning the contextual reception of everyday nationalism but instead questions the (over-) use of the term banal when thinking through how nationalism is

\footnotetext{
${ }^{1}$ The definitions Malvinas and Falklands are used interchangeably in this paper depending on whether the Islands are being referred to from an Argentine or Falkland Islands-UK perspective. Occasionally, Falklands/Malvinas is used when making general reference to the Islands across contexts. Although geopolitically charged, this naming is not intended to demonstrate support for the respective sovereignty claims of Argentina or the UK.
} 
reproduced by the nation-state. Are these expressions of nationalism always as banal as has been suggested by Billig and authors who have readily adopted his terminology? In other words are they always "so lacking in originality as to be obvious and boring" (Oxford Dictionaries, 2013). The paper looks specifically at expressions of nationalism within teaching materials in secondary schools in Argentina and the Falkland Islands to show that in these contexts, markers, symbols and references to what constitutes the nation-state need to be made mindful to young people (Billig, 1995: 38; Scourfield et al., 2006). In other words, these are not mindless 'flaggings' of the nation but deliberate, creative and original representations and reproductions of nationalism. Curiously, educational spaces receive very little attention in Billig's (1995) seminal text on banal nationalism, aside from a short caveat about the visibility of the national flag in US classrooms. This is all the more puzzling when one considers the central role of education in reminding young citizens about their national identity and issues of importance to the nation-state (Scourfield et al., 2006). This may be symptomatic of the general invisibility of childhood and associated spaces in social science research on nationalism and political geographies, particularly acute in the latter years of the last century (Kallio and Häkli, 2013; Skelton, 2010). The dearth could also be attributed to the fact that the conscious 'flagging' of citizenship and nationalism in the classroom does not conveniently fit in with Billig's (1995: 38) claim that, "reminders of nationhood hardly register in the flow of daily attention". This is clearly not the case in school classrooms where young citizens overtly learn about important historical and contemporary events that hold relevance for the nation-state in which they are growing up. Thus, this paper uses teaching materials and practices in secondary school classrooms in the Falkland Islands and Argentina to suggest there is very little that is banal about these specific representations and reproductions of nationalism. In particular, the history, geography and geopolitics of the Falklands/Malvinas sovereignty dispute are seen as critical themes in school classrooms in the Falkland Islands and Argentina which need to be explicitly signposted in order to make young citizens aware of this national issue. 
Secondly, the paper identifies the significance of localised, place-based understandings of nationalism for teachers and educational officials in Argentina and the Falkland Islands. This section takes its inspiration from existing work which has cautioned against the reification of the national-scale in studies exploring nationalism (Jones and Fowler, 2007: 333; Sabhlok, 2010). A more sensitive approach to localised interpretations of nationalism enables an exploration of how such national discourses might be reproduced, complemented and/or contested in different ways in diverse places depending on, for instance, local histories as well as the interests, backgrounds, experiences and politics of teaching staff. In the Falkland Islands there was concern with the implications of having an educational curriculum defined predominantly in the UK, in terms of what that meant for children and young people's understandings of, and identification with, the place where they grew up. This led to the introduction of what were considered more locally-relevant classes in History, Geography and Citizenship, albeit with enduring concerns with the fact that this was being delivered by teaching staff who were not from the Falkland Islands. Although the Malvinas is often framed by Argentine Presidents and politicians as a 'national cause' encouraging analyses at the national scale (see Dougherty et al. 1992; Escudé, 1987, 1988), the issue has distinctive meanings for different regions within the nation-state (author, 2011). The research for this paper was undertaken in Río Gallegos, the capital of Santa Cruz province in the austral region of Argentina, which has its own specific history of connection to the Islands stretching back many years (Mulhall, 1878; Pierini and Beecher, 2011). Educational officials and teaching staff alike were keen to make sense of the Malvinas in the classroom through these local histories (sometimes alongside nationally-produced teaching materials). There was, then, a conscious effort to ensure that understandings of national history, geography and citizenship were locally-defined in both the Falkland Islands and Argentina, albeit in distinct ways. Rather than relying exclusively on a curriculum defined from elsewhere (either the UK or the Argentine Ministry of Education respectively), there was an effort 
to frame nationalism in the classroom through a local lens which was perceived to make the topic more tangible and pertinent for young people.

\subsection{Nationalism: looking beyond the little things}

The fusion of a piece of land with the symbolic and mythified history of the nation is what gives nationalism such symbolic power immediately related to the sites and circumstances of everyday life (Agnew, 2004: 227).

The popularity of Billig's (1995) notion of banal nationalism has had a range of implications for understandings of national identity and its reproduction in what might be termed the Euro-American world. It has undeniably encouraged scholars to focus attention inwards, broadening understandings of how and where nationalistic expression can be manifest by drawing attention to the little things, acts or words which serve to remind 'us' of 'our' national identity (Flint, 2011; Thrift, 2000). The text has been extremely useful for those interested in expressions of nationalism and has wide appeal illustrated by the body of work which has emanated from Billig's ideas (e.g. Airriess et al., 2012; Batuman, 2010; Brunn, 2011; Child, 2005, 2008; Ozkirimli and Yumul, 2000; Penrose, 2011; Raento, 2006; Raento and Brunn, 2005; Webster, 2011). Yet the bulk of this research has explored a limited form of nationalistic symbolism that, while subscribing to Billig's thesis, perhaps unwittingly marginalises other more overt representations and practices which also reproduce nationalism in daily life. Billig (1995: 38) is specifically interested in reminders of nationhood which "operate mindlessly, rather than mindfully" and subsequent research has tended to look at/for representations of nationalism which might typically have been considered insignificant and unremarkable (Jones and Merriman, 2009). These studies have analysed how (usually adult) citizens are reminded of nationalism in banal ways through representations depicted on licence plates, currency, postage stamps, maps or the national flag which hangs innocently 
from public and private buildings. The use of the word banal to classify such expressions of nationalism has received a cogent critique through research on bilingual road signs in Wales. Jones and Merriman (2009: 167) state that "symbols of the nation are interpreted in different ways by different people: some in banal and unconscious ways; others in a more conscious and overt manner". This work shows that far from being mindless and mundane, the reception of everyday nationalism through objects such as road signs can instil a sense of oppression and contention among citizens. This paper is not concerned with the appropriateness of the terminology used to frame expressions of nationalism in relation to their reception per se. Rather it seeks to highlight some of the problematic consequences for understandings of nationalism, which are, in part, a result of an overwhelming interest in what has become commonly understood as the banal. The attention directed towards these banal reminders has meant that more blatant or deliberate expressions of nationalism have been neglected, which in turn has left certain spaces and citizens on the margins of research into nationalism (Flint, 2011).

It is clear that not all expressions of nationalism in "established nations" can be categorised as banal, a point that Billig would readily concede. Indeed, his work should not be read as an all-encompassing definition of how nationalism is represented in such societies, but instead as a call to researchers to illuminate that which "is so familiar and habitual that it passes unnoticed" (Billig, 2009: 349). The challenge has been readily embraced by sociologists, as well as political geographers who have sought the most obscure and unremarkable exemplars of banal nationalism in order to underline their significance in the reproduction of nationhood. This work has been valuable in shedding light on previously overlooked displays of nationalism but has, it is suggested here, come at the expense of considering spaces and times where representations and reproductions of nationhood are more explicit (Mitchell and Elwood, 2013). One such space which is ripe for further interrogation in this regard is the school classroom, educational resources and the citizens (teachers and young people) who engage with 
them (Hopkins, 2010; Pykett, 2009, 2012; Schlosser et al., 2011; Scourfield et al., 2006). Educational spaces receive very little attention from Billig (1995: 2) and in subsequent studies on banal nationalism (Scourfield et al., 2006 being a clear exception), which is odd given the emphasis in this work on trying to understand how Western publics are encouraged to identify with the nation.

Of course, these reminders of nationalism are not restricted to the institutional spaces and times of the school and might also encompass exposure to some of the things (e.g. flags, magazines, postage stamps, television programmes and so on) that have traditionally received attention from those exploring banal nationalism (Scourfield et al., 2006: 9). Furthermore, children and young people's knowledge about the nation may be constructed more broadly through their engagements with public space and, for instance, things like official monuments commemorating the nation's war dead or unofficial murals representing particular interpretations of nationhood (Hopkins, 2010). For instance, Mills' (2012) research also shows how non-school spaces can play a critical role in national citizenship training through youth movements such as the Scouts. Relations with people around children and young people are also critical to consider, in terms of thinking through the intergenerational transfer of knowledge and memory in young people's political formation (Mitchell and Elwood, 2013: 33; Penrose, 2011; Philo 2011). Mitchell and Elwood (2013: 35) call for equal interest in the spatial and temporal dynamics of how young people learn about the political, recognising that their knowledge is often constituted in relation to the past. The consequence of research which prioritises "the mundane world of the everyday, and the banal practices associated with small, seemingly insignificant interactions occurring in the present...is that they often lack an opening or appreciation for historical and/or futurist modes of thinking, relating or imagining" (ibid: 34). There is, then, considerable scope for exploring the ways in which children and young people are reminded of their national identity across different spaces and times, as well as through their engagement with different media and representations (Scourfield et al., 2006). Future research must 
remain open to exploring the potentially mindless/banal and mindful/deliberate expressions of nationalism that children and young people engage with rather than (unconsciously) prioritising one form over another (Müller, 2011: 1).

Institutional spaces and education are not just overlooked by Billig and have remained marginal topics particularly in International Relations research, a point which could be extended to Political Geography and Critical Geopolitics more generally (Hopkins, 2010; Müller, 2011; Pain et al., 2010; Skelton, 2010). And yet national educational curriculums delivered in the school classroom are often highly geopolitical and replete with references to nationhood with their emphasis on "state formation and the education of 'good citizens,' instilling loyalty to the state and patriotic thinking" (Müller, 2011: 1; Pykett, 2012). The examination of educational resources in relation to national identity and geopolitics in an Argentine context does have some historical precedent (Escudé, 1987, 1988; vom Hau, 2009). Through the analysis of geography text books published in Argentina from 1879-1986, Escudé (1987) showed how Argentine nationalism was defined predominantly through a perception of territorial loss (also see Dougherty et al., 1992). The Malvinas formed a significant part of the sense of loss throughout this period (and continues to do so in the present-day), although the extent to which text books made reference to the issue varied during the period of publication under investigation in Escudé's study. Escudé (1987: 141) sees the contents of Argentine primary and secondary school geography text books as central to the development of what he terms a "pathological territorial nationalism" where Argentines are taught about their inalienable rights to an "imaginary territory". Here, Escudé (1988: 158) refers to the abundance of graphical representations of Argentine sovereign territory in educational materials, the popular press and maps of the nation which include territories not internationally recognised as constituting Argentina. These include the Malvinas, a number of South West Atlantic territories and Argentine Antarctica, where Argentina's territorial claims overlap with those of both the UK and Chile 
(Dodds, 2002). Escudé (1987) speculates on the frustrations that such "imaginary" territorial representations might generate in Argentine citizens, but does not explore how such discourses are actually received by people in Argentina (author, 2011).

Escudé's work is useful in a general sense for underscoring the significance of national education programmes in the formation of young citizens, something which, as has been indicated, has received scant attention. However, the study is somewhat outdated (even if many of the insights concerning Argentine territorial nationalism and education are still relevant) and relies on a rather static, representation-based analysis of school text books. More recently Müller (2011: 16) has stressed that,

An international political sociology of education...cannot stop at examining text books and other educational material. For the disciplinary mechanisms of education and their implication in the formation of geopolitical subjects do not feature in text books. Only a situated perspective on geopolitical discourses can tease out how geopolitical subjectivation works on the ground, how it produces docile bodies and where it fails to do so, how it replicates the official discourse, and where it diverges from it. This spells out the case for a perspective that takes seriously the practices involved in the education of geopolitical subjects.

Müller's work calls for engagement with the "subjects" (teachers, educational officials and young people) of national education (Penrose, 2011), a definition which appears to downplay their capacity as agents who have a collective ability to contest, subvert, resist and replicate "official discourse" (Coles, 1986). The research in this paper examines contemporary educational resources such as curriculums and text books from the Falkland Islands and Argentina which focus on the South West Atlantic Islands. Yet, it goes further by looking to understand how these discourses are used (if at all) and interpreted by 
teachers and educational officials (Sabhlok, 2010). It suggests that there are local geographies to the interpretation of national educational resources and the discourses therein (Pykett, 2012: 33), which shape the ways in which the Falklands/Malvinas is taught within school classrooms across the respective research sites. ${ }^{2}$ This is aligned with existing research on nationalism which has called for 'situated', 'placed' or 'localised' understandings of nationalism, as opposed to restricting analyses to the national scale (Agnew, 2004; Airriess et al., 2012; Jones and Desforges, 2003; Sabhlok, 2010). Jones and Fowler (2007: 335) persuasively argue "that it is only by examining places that we can actually truly understand how national identities are accommodated within the worldviews of individuals or, in other words, how nations are consumed and reproduced". Critically, this is a multi-scalar approach which does not focus on the local at the expense of all other spatial scales but instead sees the nation "as something that is actively produced out of its connections with the local, the regional, the international, and the global" (Jones and Fowler, 2007: 338. For cogent discussions of scale and research with young people see also, Ansell, 2009; Hopkins and Alexander, 2010). Jones and Desforges (2003: 277) posit that "people, living in different places, will make sense of more general conceptions of the nation in a variety of ways...[and] their own sense of nationalism will be informed by other processes taking place within their own locality".

\subsection{Researching the Falklands/Malvinas dispute}

This research was undertaken amidst a marked 'heating up' of diplomatic exchanges between Argentina and the UK over sovereignty claims pertaining to the Falklands/Malvinas Islands (see author forthcoming; Dodds, 2012; author, 2010). The Falkland Islands Government (FIG) has also been active in

\footnotetext{
${ }^{2}$ The work presented in this specific paper is drawn from the first stage of a larger Leverhulme-funded project which will subsequently work alongside young people aged 17-20 from the Falkland Islands, the UK and Argentina. This will explore the extent of their knowledge about the history, geography and contemporary geopolitics of the Islands and will importantly look to understand the complex ways in which such discourses are received (see author, 2011).
} 
a diplomatic sense, despite Argentina's refusal to engage in dialogue with representatives from the territories, embarking on visits to meet diplomats in Europe and the Americas to present their case for self-determination. These visits came on the back of a referendum which took place in the Falkland Islands in March 2013 (Dodds and Pinkerton, 2013), where 99.8\% of eligible voters on the electoral register responded in the affirmative to the question: Do you wish the Falkland Islands to retain their current political status as an Overseas Territory of the United Kingdom? The referendum was an opportunity for Falkland Islanders to have their voice heard by the international community and was, in part, set up in response to persistent pressure from Argentina, which has sought to disrupt trade and tourism links between the territories and Latin American ports (Short, 2012).

In Argentina, the 'Malvinas cause' has been an important foreign policy priority for military and democratic administrations alike since the middle of the twentieth century (this is not to suggest that Argentina did not claim sovereignty before then but that domestic interest in the issue intensified in the 1940s, followed by international diplomatic efforts at the UN in the 1960s, Escudé, 1987, 1988; Iglesias, 2012; Pascoe and Pepper, 2012). The infamous 1982 invasion of the Islands under the stewardship of a military junta in the throes of civil and economic collapse domestically, resulted in ignominious defeat for Argentina's forces and more poignantly the death of hundreds of Argentine and British servicemen, as well as three civilians from the Falkland Islands. Just over 20 years later, the election of Néstor Kirchner saw a shift in Argentine government attitudes towards the sovereignty question as he set about revoking previously-held agreements with the FIG regarding fishing and mineral exploration, instead placing an emphasis on resuming sovereignty negotiations (rejected by the British government and the FIG as they maintain that self-determination non-negotiable, see author, 2010). These policies have been reinforced by the late Néstor's spouse, Cristina Fernández de Kirchner, who has consistently used bilateral, regional and global platforms to propagate Argentina's "imprescriptible" sovereignty rights to 
the territories. The Kirchner administrations have cited the pitfalls of desmalvinizacion, an approach critiqued for its conciliatory and softer diplomatic stance, which characterised the presidency of Carlos Menem from 1995-1999 (e.g. entering into direct negotiations with the FIG and thereby recognising the status and rights of the FIG and Falkland Islanders more generally, see Dodds, 2002).

The term is also used more generally by veterans and supporters of the 'Malvinas cause', when referencing the need to ensure that young Argentine citizens born after the 1982 conflict do not forget about the Islands and their significance to the nation and national identity. The school is seen as a key site through which young people learn about Argentine "territorial integrity" and their "legitimate rights" to the Malvinas, other South West Atlantic territories and a large sector of Antarctica. The presence of the Malvinas in educational resources and school classrooms throughout Argentina has a long history (Escudé, 1987) but in recent years there has been a notable surge in dedicated Malvinasthemed materials (e.g. documentaries and cartoons on DVDs, poetry books, posters, maps, text books) produced by the Ministerio de Educación de la Nación Argentina and others (e.g. Malvinas Observatorio, 2011). This mirrors the grander foreign policy objectives of Argentina, as well as the Argentine Constitution (the transitional provisions amended in 1994 state that, "The recovery of these territories [the Malvinas, Argentine Antarctica and other South West Atlantic islands] and the full exercise of sovereignty...constitute a permanent and unwavering goal of the Argentine people, Constitución de la Nación Argentina, 1994) and corresponds with the Kirchner-inspired push to interrogate memory, truth and human rights, primarily in relation to abuses committed during the last dictatorship from 1976-1983 (Ros, 2012; including violations committed during the Malvinas campaign against young conscripts, see Dobry, 2012; Lorenz, 2006; Niebieskikwiat, 2012). 
Although in different ways, education in the Falkland Islands has been identified more recently as fundamental in the formation of 'well-informed' national citizens. This has led to greater engagement with local history and geography to complement the otherwise British-dominated curriculum which is taught in the Islands. While primarily focusing on aspects of life in the Falkland Islands, teachers also explore the geopolitical dispute with Argentina, examining the historical evidence for the respective sovereignty claims as well as the 1982 war and more recent tensions over fishing and oil exploration. While by no means the principal objective of teaching this local content, several teachers and FIG officials cited the importance of young people being able, if confronted, to respond intelligently to the questions of journalists visiting the Islands.

The empirical data presented in this paper was gathered during a visit to the Falkland Islands which took place a month after the culmination of the $30^{\text {th }}$ anniversary of the 1982 war and one month before the 2013 referendum which collectively saw hundreds of journalists from all around the world stay in the territories. Hence, there were acute sensitivities about how the Islands were being projected to the world and young people were considered to play a critical role in these representations of Falkland Islanders. Young ambassadors (aged 25-30) from the Islands have also been given prominent roles in formal diplomatic visits to countries in Latin America, as well as the UN. Member of the Legislative Assembly (MLA) Gavin Short stated that during these visits having the "voice of an ordinary citizen was far more powerful than that of a wrinkly old politician as people expect us to say certain things. When an ordinary person freely expresses the same opinions most eloquently then real attention is paid" (Mercopress, 2013). So, the embodied notion of the 'ordinary' young citizen, set apart from the archetypal older statesperson, does important work here in a diplomatic sense as it shows off an eloquent, dynamic and youthful citizen (suggestive of the 'the next generation') from the Falkland Islands to a Latin American audience (Evans, 2010). These visits were also an opportunity to school 
potential future leaders from the Falkland Islands who may eventually become MLAs and partake in similar diplomatic activities.

The work presented in this paper is drawn from a research visit to Port Stanley in the Falkland Islands, and to Río Gallegos and Buenos Aires in Argentina. The focus of the trip was to examine how young people attending secondary schools were being taught about the Falklands/Malvinas issue in the Islands and in Río Gallegos, a city chosen because of its strong historical links to the Islands. Extensive semistructured interviews were undertaken with relevant teaching staff at the only secondary school in the Falklands (FICS), primarily the head teacher and member of staff responsible for delivering Citizenship classes. Educational and government officials were also interviewed alongside the analysis of curriculums and teaching resources utilised in the FICS. Staying in the Islands enabled more general participant observation and insights in the paper are also drawn from field diary entries. In Río Gallegos interviews were conducted with eight members of staff responsible for teaching history in seven secondary schools (four public, two private and one Catholic school which was private although not as expensive and therefore exclusive as the other private institutions involved). This sample selection reflected the wider population of schools in the city of Río Gallegos in terms of the mix between public and private institutions. Educational officials were interviewed at the provincial (Santa Cruz) and national level; the latter representatives coordinated the design and publication of educational resources related to memory and the Malvinas for schools throughout Argentina. Finally, the Minister of Education for Argentina, Alberto Sileoni, was interviewed in order to understand how the Malvinas was conceptualised at the national-scale and how that might differ in a region like Santa Cruz.

Although not the primary focus of this paper, the nature and locations of the research made it imperative to reflect constantly on my positionality as a researcher (e.g. Katz, 1994; Keith, 1992; Rose, 
1997), and in particular on my national identity. My field diary regularly reflected on how it felt to be a British researcher in both the Falkland Islands and Argentina:

An Islander told me that there is the potential for me to be viewed with suspicion because of the incorporation of Argentine views in my research and that people here in the Falklands have been subject to a lot of media attention in recent years. Often they have provided interviews in good faith only to have their views twisted in some way just to jazz up a story (field diary extract, 15/02/13).

There was, then, a mild suspicion directed towards journalists and researchers who came to the Islands from the UK to write about the Islands and their way of life, particularly if there was potential for these accounts to explore and be sympathetic to (as some journalists have been, see Milne, 2013) Argentine perspectives and arguments relating to the Islands. Given the well-documented Anglo-Argentine political tensions I had expected to encounter obstacles to accessing teaching staff, officials and politicians in Argentina.

There was no overt distrust directed towards me as a result of my nationality in Argentina (indeed, my 'outsider' status in Río Gallegos was curiously beneficial given the remoteness of the location and the rarity of overseas and more specifically British researchers undertaking work there), but that is not to suggest that it did not influence my research and everyday encounters. All of the interviews were undertaken in Argentine Spanish, yet my respondents were very aware that they were speaking to a British researcher who would be publishing academic work in English. Indeed, some of the politicians and educational officials saw this as an opportunity to put across their perspectives on the Malvinas question to a British audience. This could have also meant that some respondents were guarded in what they disclosed, for instance, choosing to reproduce the arguments of the nation-state over and above 
more personal reflections. The temporal and spatial aspects of the research across all the sites must be critically considered here. The research took place in the midst of extremely fraught relations between the UK, Argentina and the Falkland Islands meaning that officials, politicians and in some instances teachers needed to be even more careful about what they said. The majority of the interviews took place in the offices of politicians or on school premises as opposed to more informal settings, which perhaps amplified the tendency to reproduce the 'official' line. Despite this, many respondents offered opinions that were surprising in ways which belied the wider geopolitical dynamics of the moment.

\subsection{Banal nationalism? The secondary school classroom}

Issues relating to the Islands are a substantial part of secondary school educational curriculums in the Falkland Islands and Argentina, spanning a diverse range of subjects from History, Geography, Citizenship Studies and more. Of course, there are different dynamics at play here given that young Falkland Islanders are learning about the place in which they are growing up, while young Argentines learn about a place that many have never visited but are told forms an integral part of their nation (Escudé, 1988). This paper cannot discuss the entire contents of the respective curriculums but instead picks on some emblematic examples of activities and resources which show how nationalism expressed in the classroom is often creative, original (hence, far from banal) and demanding of greater attention from scholars interested in the expression and formation of national identity (Scourfield et al., 2006). The $30^{\text {th }}$ anniversary of the Falklands/Malvinas war in 2012 was a particularly poignant and significant moment for many people in Argentina and the Falkland Islands (as well as the UK). This was reflected in the FICS where for one week the school had dedicated classes on the Falklands war as the head teacher explained: 
We had a collapsed timetable to coincide with the 30th anniversary commemorations where we spent a week on individual activities within each class and within each subject that were related to commemorating the 30th anniversary of the conflict. So, for example, in Arts, they produced a mural (Fig. 1), in Design Technology, they worked on reproducing some of the crests associated with each of the units that were posted here. In PE, they worked on looking at the PT [Physical Training] that the military underwent in preparation to arrive on the islands. In English, they looked at war poetry in general, so not just from the 1982 conflict...in Geography, they looked at some of the mapping of where the key principle conflicts occurred and they looked at lots of historical maps from the era and looked at some of the challenges that were faced in that method. Obviously, History covered it from a historical perspective.

In some ways 2012 was an exceptional anniversary year, in terms of the time dedicated to the topic and the focus on the 1982 war in schools in Argentina and the Falklands. The classes were carefully planned and coordinated to encourage young Islanders to engage in creative ways with the war within the parameters of the different scholarly disciplines offered by the school. These were far from banal or subtle references to nationhood and represent a more explicit, deliberate and sustained effort to remind young citizens of the sacrifices made by British forces in 1982, as well as the historical and contemporary consequences of the war for life on the Islands. Notwithstanding the significance of the anniversary year, these engagements remain illustrative of the ways in which young Islanders learnt more about an event central to the national identity of the place in which they live, but that they did not experience directly. Key dates marking anniversaries relating to the 1982 conflict (and other events including the Battle of the Falklands Islands which commemorates the British naval victory over a German cruiser squadron in the South Atlantic on the $8^{\text {th }}$ December 1914) were central to Islander 
identity and the Citizenship teacher at the FICS explained why this was the case for children and young people in particular:

So, for Falkland Islanders, Liberation Day [ $14^{\text {th }}$ June, the day of the Argentine surrender in 1982] is still a very important and poignant day because the actual conflict hasn't gone away; not properly. It's still very much there. So it's important that our children get an opportunity to express how they feel at that particular time. All sorts of emotions come out because they see their grandparents upset. They see their mothers and fathers, who may have been locked up at Goose Green upset. So for Falkland Islanders this really hasn't gone away. It's still very much something in the forefront of their minds. So you can never ignore ' 82 but I need to make sure that we don't dwell on 1982 because, as I say, I really feel that there's so much more to being a Falkland Islander than what happened then.

The 'live' nature of the dispute with Argentina with its effects on trading and economic links, and the omnipresence of the 1982 war referred to here in relation to the affective responses of older family members, meant that national anniversaries were considered significant for young people. ${ }^{3}$ There were, then, overt and tangible connections between what young people learnt about nationhood in the classroom and elsewhere through the family and at public commemorative events (Hopkins, 2010; Scourfield et al., 2006). Billig's (1995) banal nationalism underplays some of the potential connections between different spaces and manifestations of nationalism, instead placing emphasis on somewhat isolated things, events or language used in news reporting and politician's speeches. This has had subsequent knock-on implications for the focus of social science research which has tended to look at

\footnotetext{
${ }^{3}$ Although the 1982 war featured heavily in the curriculum especially in the $30^{\text {th }}$ anniversary year it was clear that teaching staff did not want it to dominate entirely, as suggested in the extract above. The Falkland Islands Citizenship curriculum covered themes of communication within and beyond the Islands, Islander identity, the economy, the role of the military, the functioning of the FIG, the Islands' Constitution, as well as the early history stretching back to the first discovery and settlement of the territories.
} 
expressions of nationalism through specific signifiers like license plates, postage stamps and flags. The significance of such banal 'things' alongside other practices, including the intergenerational transfer of nationhood (Ros, 2012), across different spaces (e.g. public and classroom spaces) have yet to be fully explored by scholars undertaking research into nationalism (Müller, 2008, 2011).

In Argentine secondary schools, the Malvinas element of the curriculum is delivered predominantly through classes focusing on national history; symbolically important, as according to Argentine maps the Malvinas constitute part of the province of Tierra del Fuego and hence are defined as sovereign national territory (Escudé, 1988). Anniversaries related to the Malvinas are also significant and principal among these is the $2^{\text {nd }}$ of April (the date in 1982 when Argentine forces "recuperated" sovereignty of the Islands), which is generally marked in most institutions with an acto or ceremony where speeches are read and a rousing march about the Malvinas is played (although with considerable variation in how much time and effort was placed on the organisation of Malvinas actos across schools, see section 1.5). To facilitate the teaching of the Malvinas the Ministerio de Educación de la Nación (Argentina's Ministry of Education) has produced a range of text books and DVD resources for circulation in private/public primary and secondary schools. In 2012 a booklet and poster were published by the Ministry, in conjunction with academics and provincial education departments, for secondary institutions which jointly represent the "Malvinas as a cause that is present in every corner of the homeland". The large poster consists of a map of Argentine territory (including the South West Atlantic territories and Argentine Antarctica) labelled with numerous references to the Malvinas which are evident in public space throughout the nation (Fig. 2), which the accompanying booklet/teaching aid then elaborates on. These are split into themes of sovereignty, the war and memory and consist of, for example, an airport named after the Islands in Rosario, a school named after the General Belgrano in Salta (the infamous 
Argentine navy cruiser sunk by the HMS Conqueror during the war) and even an ice cream parlour in Buenos Aires called Heladería Las Malvinas.

These are precisely the kinds of banal, everyday reminders of nationhood, or in this case territorial nationalism, that Billig might have been occupied with. However, it would seem that there is concern from the Argentine state that the banal 'flagging' of nationhood through the naming of buildings, streets, neighbourhoods and stadiums is not doing enough 'work'. Thus, there is a need to make these 'mundane' references noticed in order to maintain the visibility of the Malvinas in Argentine public spaces, precisely so they are not forgotten by younger generations of Argentine citizens born after the 1982 war. Moreover, the project includes an interactive element on the website of the Education Ministry which encourages "students and teachers throughout the country to participate and continue collectively constructing the map" by adding other Malvinas references present in the everyday spaces they encounter (Ministerio de Educación de la Nación Argentina, 2012: 16). These kinds of explicit reminders of nationalism in relation to educational resources for young people would appear to disrupt Billig's and others' preoccupation with banal expressions of nationalism. In what ways might we rethink and refocus these theorisations of nationalism if we consider young people/citizens who need to be consciously schooled and reminded (from the perspective of the nation-state) about issues central to national identity? These are not banal, unconscious reminders of Argentine territorial nationalism; rather they are carefully planned, creatively produced expressions which encourage citizen participation and represent a deliberate attempt to reproduce a national identification with specified causes of the nation. 
There had been an effort in the Ministry to broaden teaching about the Malvinas 'cause' specifically, in some ways mirroring the concerns of teaching staff in the Falkland Islands regarding the 1982 war and its potential to dominate:

The Malvinas come to constitute an educational agenda that engages very seriously with, on the one hand, a traumatic episode of the recent Argentine past like the dictatorship, and on the other, the necessity to form citizens with an identity, who think about the country and its relation with politics and the destiny of the continent...neither do we reduce the Malvinas to the war. The Malvinas is an issue with a long history in Argentina and it's a claim that is held in our democratic Constitution, therefore, this demands that we have a wider view about the issue, not only identifying with the war (Coordinator of the Education and Memory Programme, Ministerio de Educación de la Nación Argentina, author's emphasis).

The Malvinas was seen as central to the formation of Argentine national identity and it was constantly stressed by educational officials in both research locales that there was an extensive history of connection to the territories which stretched back many years (i.e. far beyond 1982). This was perceived to be a critical part of teaching the Islands' history in both Argentina and the Falklands, which carried implicit geopolitical undertones as the respective historical accounts highlighted the basis and longevity of Argentine and British territorial claims (see Pascoe and Pepper, 2008). Increasingly, and in line with Argentine foreign policy statements, text books and documentaries on DVDs distributed by the Ministry of Education refer to the Malvinas as a regional, Latin American 'cause' (Observatorio Malvinas, 2011; Puntigliano, 2011). Rather than solely instilling a sense of Argentine nationalism, there have been efforts within educational resources to evoke a Latin American 'regionalism', by referencing the consistent support Argentina has formally received for its Malvinas claim from organisations like UNASUR, 
MERCOSUR and CELAC (author, 2011: 449). There are interesting scales of identification with both the national and supra-national being advanced here (Billig, 2009), the latter of which has received scant attention in research on the South West Atlantic given the tendency to frame the Malvinas as a strictly nationalist concern. The next section incorporates another scale, showing how national educational discourses and resources were utilised, contested and/or accompanied by localised understandings of the Falklands/Malvinas (Jones and Desforges, 2003; Jones and Fowler, 2007).

\subsection{Interpreting nationalism locally}

We try to make sure the message [relating to the Malvinas], the importance it's given and the way it is taught is as similar as possible. In a federal nation-state there are particularities. I have the conviction that in all the provinces the issue is treated with the maximum importance, with the maximum dedication...It might be that a specific teacher puts more emphasis and more passion into the issue than others and for others it might be less important and one notices this the moment when it is taught...At least our obligation from here [the Argentine Ministry of Education] is to make sure that things are taught with truth, with scientific and historical rigour.

The Argentine Minister of Education and staff at the Ministry more generally were realistic about the diverse ways in which the Malvinas might be interpreted by provincial educational departments and teachers within schools. The educational resources produced by the Ministry were seen as teaching aids which presented suggested activities for the classroom rather than strict guidelines on how the Malvinas must be taught. Furthermore, the Malvinas was acknowledged as having localised connotations that varied throughout Argentina as a consequence of the 1982 war and these were seen by the Education Minister as having a potential influence on teaching delivery: 
Of course, the southern provinces were much more involved [during the war]. In the more distant provinces, you know that the war coincided with the World Cup [1982], so there the attention was dispersed but there are many regions of the country...I'm thinking about the province of Corrientes, some of the northeast provinces of Argentina sent lots of young men to the war...so there the feeling is much more important, more profound.

Santa Cruz makes up one of the southern provinces that the Minister alludes to here and the provincial capital Río Gallegos has a long history of connection to the Malvinas, not only associated with the 1982 war (Graham-Yooll, 2007; Pierini and Beecher, 2011). There was a concerted effort on the part of provincial educational officials and teachers to utilise this local history when teaching the Malvinas but this was done in markedly different ways. For instance, several officials at the provincial educational department were involved in constructing a website for use within secondary school classrooms which focused directly on the war as it was lived by civilians in Santa Cruz:

This project is focused on the conflict and it's called 74 days. The objective is the construction of social memory about what the Malvinas means in Santa Cruz...In this project the Malvinas are not analysed from the point of view of the military...we explore it from multiple perspectives. What happened to those who were in Santa Cruz at the time? [...] And also it [the project] makes connections between the school and the community so that the school leaves the confines of its walls and goes to ask questions of its neighbours to ask what happened here?

Many of the schools (public and private) involved in this research also looked to organise events which enabled young people to get a better sense of what life was like in Río Gallegos before, during and after the Malvinas war in 1982. Members of the local community, veterans and historians were typically 
invited to organised assemblies within the schools where young people were given the opportunity to ask questions relating to their experiences of the war. Some of the schools also arranged trips to the local Malvinas museum run by war veterans or walkabouts where they visited key monuments in the city. In one public school there was a member of staff who had personal connections to the war having lost a close family member and he presented his story to the young people each year on the $2^{\text {nd }} \mathrm{April}$. Almost without exception all adults who had lived in Río Gallegos in 1982 (many teachers were from other provinces in Argentina, hence the need to engage with local community members for these accounts) were able to recall their experiences of blackouts, simulated attacks where they were required to hide under desks and watching military planes leave and often not return to base. There was, then, considerable emphasis placed on understanding this key element of Argentine national identity through local stories, histories and personalities over and above educational resources and discourses produced by the nation. The text book and DVD resources from the National Ministry of Education were sometimes used to complement teaching on the Malvinas in schools in Río Gallegos, yet some teachers admitted to never having looked at them.

Although this 'placed' understanding of the Malvinas was common across schools in Río Gallegos (Jones and Fowler, 2007), the ways in which the topic was taught in the classroom (the amount of time it was afforded, the kinds of resources used and the extent to which reference was made to the 1982 war) ultimately seemed to depend on decisions taken by individual schools and teachers. History teachers in private schools seemed more likely to take alternative approaches, and the extract below is emblematic of this:

Regarding the testimonies of ex-combatants, firstly, I've never invited them to my classes or for the $2^{\text {nd }}$ of April and I consider it a very partial vision, very subjective and not very critical of the war. An ex- 
combatant who suffered and saw his fellow soldiers killed cannot make one understand this war. Last year...as it was the $30^{\text {th }}$ anniversary it started to come to the fore and there was going to be protests and everything else and I said, 'No, I'm not going to get caught out again by this'...we explore the Malvinas from other angles, not the war.

This teacher looked at Malvinas history by deliberately avoiding the war, which she considered to be problematically dominant in discourses from the Argentine Education Ministry. As indicated earlier, there was an insistence from the Ministry that the Malvinas was far more than 1982, yet some teachers expressed frustration with the amount of attention it received. There was a preference here for issues which the teacher perceived to be more conducive to critical debate (as opposed to relying on "subjective" personal testimony of local citizens or veterans, for instance) such as the colonial history associated with the region, nineteenth and twentieth century migration between the Islands and the province of Santa Cruz, and contemporary issues related to the economy of the Islands and exploitation of hydrocarbons. Another private school in Río Gallegos was keen to foment critical debate about the Malvinas question, as opposed to simply reproducing the nationalist line, and took an approach that was neither pro-Argentine, nor pro-British. Instead, the young people engaged with a range of different books and internet sources that detailed the position of the British, Argentine and Falkland Islands governments in order to construct an independent argument on a topic of their choice related to the territories. There was a frustration in this school, at least, at what teachers perceived to be a lack of critical interrogation and understanding behind the ubiquitous phrase, 'Las Malvinas son Argentinas', and for this reason they encouraged young people to explore the issue from distinctive angles, including those not necessarily covered by educational resources published by the national government. 
A determination to define and interpret the educational curriculum locally was also evident amongst teaching staff in the Falklands Islands. The head teacher of the FICS and acting head of education at the time explained how the curriculum, largely defined in the UK, was able to accommodate local history, geography and citizenship:

Basically, we teach the National Curriculum of England and Wales here with the additions of we have a very intensive PSHE [Personal, Social and Health Education] programme and as part of that, we have a Falkland Island Citizenship programme, which is examined here on the Islands...that was developed here in the school by one of our local teachers who's had extensive experience. She has a very good in-depth knowledge of the local history and the local geography. We also have adaptations to the Geography and the History curriculum. A recent History teacher here had a keen research interest in the 1982 conflict. He was an experienced battlefield tour guide and he brought a lot of that into the History curriculum as an add-on to the UK National Curriculum.

Themes relating to the Falkland Islands were now a formally examined part of the curriculum (the Falkland Islands Citizenship course had been delivered since 2008), whereas previously teaching related to the Islands had been more dependent on individual staff members taking an interest in local history and bringing that interest into the classroom. Having staff members who were from the Islands was still considered a critical part of, firstly, developing an extensive programme of classes and, secondly, for delivering the material in an enthusiastic and knowledgeable way. Yet there were lingering concerns at the high turnover of teaching staff not from the Islands and the implications this had on the ways in which local history and geography were being taught. With considerable support from the FIG for the funding of higher education for young Islanders (typically in the UK) it was hoped that in the future more will return to teach on the Islands: 
I'm looking forward to getting more local teachers in the school because that can only be a good thing, because it creates stability plus you can bring in things like conservation related to the Falklands. Things like, old Falkland Islands sports in the PE lesson; maybe horse riding or something, I don't know. But I think having local people means that we can increase the amount of local citizenship that we can put into our lessons without too much effort. So that's good. It's got to be, hasn't it? (Interview with Citizenship teacher, FICS).

There were, then, questions of authenticity, indigenous knowledge and national identity here in relation to who was considered to be in a qualified position to teach Falkland Islands history reliably and effectively. The eagerness to include locally-defined content in the Island's classrooms should not necessarily be read as a dismissal of a curriculum which is otherwise derived from the UK. Read in the wider context of the 2013 referendum result, it is clear many Falkland Islanders are keen to retain their links with the UK under their status as a BOT and many Islanders, both young and old, are proud of their dual identification with the Falkland Islands and the UK (author, 2012; Skelton, 2005). As part of this, teaching staff and educational officials wanted to ensure that they and young people growing up in the Falklands were not subjected to a curriculum that was solely determined by the UK.

\subsection{Conclusion}

The renewed impetus to educate young people about contemporary and historical events central to notions of national identity in both Argentina and the Falklands, as well as wider conceptualisations of the role of youth in this geopolitical dispute make this an interesting and timely moment for research in the region. However, insights from this paper contribute to wider debates concerning theorisations of nationalism that extend far beyond the South West Atlantic context. Firstly, the paper argues that an 
emphasis on more banal or marginal expressions of nationalism which might be considered novel and ripe for academic attention, should not come at the expense of looking at other spaces and times where nationhood is overtly learnt. To this end, research interested in the (re)production of national identity should engage more seriously with young people, teachers and educational spaces, as well as more informal spaces where nationhood might be learnt, received and/or contested such as Scout, Brownie and other youth groups (Mills, 2012; Scourfield el al., 2006). This work should not just focus attention on representations of nationalism that can be found in classrooms and other spaces through things like text books but should incorporate the perspectives of those involved in producing, delivering and receiving such discourses. Sabhlok (2010: 748) usefully points out that by "focusing on the role of symbolic and literal language in the imagination of the nation often forgotten is the role that social practices...play in the construction of the idea of a national community." Schools and teaching staff often had a considerable amount of freedom in terms of how classes were delivered in Argentina and the Falklands, making it insufficient to refer to discourses disseminated through texts and representations published by the nation.

It is clear that expressions of nationalism in school classrooms in both the Falkland Islands and the south of Argentina cannot be understood without understanding how, "local processes and institutions can contribute in the formation and inflection of nationalist sentiment" (Jones and Desforges, 2003: 272). Research into nationalism must continue to acknowledge the relations between different geographical scales and this paper has specifically shown how regional (i.e. South American), national, provincial and localised scales are enmeshed and can determine how nationalism is interpreted and expressed. Interestingly, while national educational discourses in Argentina often prioritised more parochial framings of the dispute in the South West Atlantic, individual schools and teachers in Río Gallegos took it upon themselves to emphasise periods of relative peace and cooperation through the discussion of 
historical trade and migration links between the territories and the Argentine mainland (Pierini and Beecher, 2011). Perhaps these efforts are indicative of how the formation of nationhood in the classroom could be alternatively framed in ways which emphasise commonality, connection and conciliation in a dispute which is so often characterised by division and difference.

\section{Bibliography}

Agnew, J., 2004. Nationalism. In: Duncan, J.S., Johnson, N.C., Schein, R.H. (Eds.) A companion to cultural geography. Blackwell, Oxford, pp. 223-237.

Airriess, C., Hawkins, M., Vaughan, E., 2012. Situating banal nationalism, the culture wars, and civil religion: governing localised geographies of national identity in Indiana. Social and Cultural Geography $13,49-67$.

Ansell, N., 2009. Childhood and the politics of scale: descaling children's geographies? Progress in Human Geography 33, 190-209.

Batuman, B., 2010. The shape of the nation: visual production of nationalism through maps in Turkey. Political Geography 29, 220-234.

Billig, M., 1995. Banal Nationalism. Sage, London.

Billig, M., 2009. Reflecting on a critical engagement with banal nationalism: reply to Skey. Sociological Review 57, 347-352.

Brunn, S., 2011. Stamps as messengers of political transition. Geographical Review 101, 19-36.

Child, J., 2005. The politics and semiotics of the smallest icons of popular culture: Latin American postage stamps. Latin American Research Review 40, 108-137.

Child, J., 2008. Miniature messages: the semiotics and politics of Latin American Postage Stamps. Duke University Press, Durham.

Coles, R., 1986. The political life of children. Houghton Mifflin Company, Boston. 
Constitución de la Nación Argentina. 1994. http://www.constitution.org/cons/argentin.htm (last accessed 2 June 2013).

Dobry, H., 2012. Los rabinos de Malvinas: la comunidad judía argentina, la guerra del Atlántico Sur y el antisemitismo. Vergara, Buenos Aires.

Dodds, K., 2002. Pink ice: Britain and the South Atlantic Empire. I B Tauris, London.

Dodds, K., 2012. The Falkland Islands as a 'strategic gateway': Britain and the South Atlantic Overseas Territories. RUSI Journal 157, 18-25.

Dodds, K., Pinkerton, A., 2013, in press. The Falkland Islands referendum 2013. Polar Record.

Dougherty, K.C., Eisenhart, M., Webley, P., 1992. The role of social representations and national identities in the development of territorial knowledge: a study of political socialisation in Argentina and England. American Educational Research Journal 29, 809-835.

Escudé, C., 1987. Patología del nacionalismo: el caso argentino. Instituto Torcuato Di Tella, Buenos Aires. Escudé, C., 1988. Argentine territorial nationalism. Journal of Latin American Studies 20, 139-165.

Flint, C., 2011. Introduction to geopolitics. Routledge, London.

Evans, B., 2010. Anticipating fatness: childhood, affect and the pre-emptive 'war on obesity'. Transactions of the Institute of British Geographers 35, 21-38.

Graham-Yooll, A., 2000. La colonia olvidada: tres siglos de habla inglesa en la Argentina. Emecé Editores, Buenos Aires.

Hopkins, P., 2010. Young people, place and identity. Routledge, London. Hopkins, P., Alexander, C., 2010. Politics, mobility and nationhood: upscaling young people's geographies: introduction to special section. Area 42, 142-144.

Iglesias, F., 2012. La cuestión Malvinas: crítica del nacionalismo argentino. Aguilar, Buenos Aires. Jones, R., Desforges, L., 2003. Localities and the reproduction of Welsh nationalism. Political Geography $22,271-292$. 
Jones, R., Fowler, C., 2007. Placing and scaling the nation. Environment and Planning D: Society and Space 25, 332-354.

Jones, R., Merriman, P., 2009. Hot, banal and everyday nationalism: bilingual road signs in Wales. Political Geography 28, 164-173.

Kallio, K.P., Häkli, J., 2013. Children and young people's politics in everyday life. Space and Polity 17, 116.

Katz, C., 1994. Playing the field: questions of fieldwork in geography. Professional Geographer 46, 67-72. Keith, M., 1992. Angry writing: (re)presenting the unethical world of the ethnographer. Environment and Planning D: Society and Space 10, 551-568.

Lorenz, F.G., 2006. Las guerras por Malvinas. Edhasa, Buenos Aires.

Mercopress, 2013. Falkland Islands' delegation received in Latam with open doors and genuine interest. http://en.mercopress.com/2013/04/13/falkland-islands-delegation-received-in-latam-with-open-doorsand-genuine-interest (last accessed 18 June 2013).

Mills, S., 2012. 'An instruction in good citizenship': scouting and the historical geographies of citizenship education. Transactions of the Institute of British Geographers 38, 120-134.

Milne, S., 2013. This isn't self-determination. It's a Ruritanian colonial relic, The Guardian: comment is free. http://www.guardian.co.uk/commentisfree/2013/mar/12/falklands-vote-ruritanian-colonial-relic (last accessed 18 June 2013).

Minsterio de Educación de la Nación Argentina, 2012. Malvinas: educación y memoria. Material para trabajar en las aulas sobre historia, memoria y soberanía de las Islas Malvinas, Georgias del Sur, Sandwich del Sur y los espacios marítimos circundantes (Escuelas Secundarias).

Mitchell, K., Elwood, S., 2013. Intergenerational mapping and the cultural politics of memory. Space and Polity 17, 33-52.

Mulhall, M.G., 1878. The English in South America. Standard Office, Buenos Aires. 
Müller, M., 2008. Reconsidering the concept of discourse for the field of critical geopolitics: towards discourse as language and practice. Political Geography 27, 322-338.

Müller, M., 2011. Education and the formation of geopolitical subjects. International Political Sociology

5, 1-17.

Observatorio Malvinas, 2011. Malvinas en la historia: una perspectiva suramericana. Universidad Nacional de Lanús.

Oxford Dictionaries, 2013. Banal. http://oxforddictionaries.com/definition/english/banal (last accessed 16 June 2013).

Ozkirimli, U., Yumul, A., 2000. Reproducing the nation: banal nationalism in the Turkish press. Media, Culture and Society 22, 787-804.

Niebieskikwiat, N., 2012. Lágrimas de hielo: torturas y violaciones a los derechos humanos en la guerra de Malvinas. Grupo Editorial Norma, Buenos Aires.

Pain, R., Panelli, R., Kindon, S., Little, J., 2010. Moments in everyday/distant geopolitics: young people's fears and hopes. Geoforum 41, 972-982.

Pascoe, G., Pepper, P., 2008. Getting it right: the real history of the Falklands/Malvinas. http://www.falklandshistory.org/ (last accessed 16 June 2013).

Pascoe, G., Pepper, P., 2012. False Falklands history at the United Nations.

http://www.falklandshistory.org/ (last accessed 12 June 2013).

Penrose, J., 2011. Designing the nation. Banknotes, banal nationalism and alternative conceptions of the state. Political Geography 30, 429-440.

Philo, C., 2011. Foucault's children. In: Holt, L. (Ed.) Geographies of children, youth and families: an international perspective. Routledge, London, pp. 27-54.

Pierini, M., Beecher, P., 2011. Cien años del club británico de Río Gallegos: los británicos en Santa Cruz. Club Británico de Río Gallegos, Río Gallegos. 
Puntigliano, A.R., 2011. 'Geopolitics of integration' and the imagination of South America. Geopolitics $16,846-864$.

Pykett, J., 2009. Making citizens in the classroom. An urban geography of citizenship education. Urban Studies 46, 803-823.

Pykett, J., 2012. Making 'youth publics' and 'neuro-citizens': critical geographies of contemporary education practice in the UK. In: Kraftl, P., Horton, J., Tucker, F. (Eds.) Critical geographies of childhood and youth. The Policy Press, Bristol, pp. 27-42.

Raento, P., 2006. Communicating geopolitics through postage stamps: the case of Finland. Geopolitics $11,601-629$.

Raento, P., Brunn, S.D., 2005. Visualizing Finland: postage stamps as political messengers. Geografiska Annaler 87 B (2), 145-163.

Ros, A., 2012. The post-dictatorship generation in Argentina, Chile, and Uruguay: collective memory and cultural production. Palgrave Macmillan, Basingstoke.

Rose, G., 1997. Situating knowledges: positionality, reflexivities and other tactics. Progress in Human Geography 21, 305-320.

Sabhlok, A., 2010. National identity in relief. Geoforum 41, 743-751.

Schlosser, K., White., G., Leib, J., Dalby, S., Algeo, K., Jansson, D., Zimmerman, J., 2011. Nationalism in Geography classrooms: challenges and opportunities. Journal of Geography 110, 166-175.

Scourfield, J., Dicks, B., Drakeford, M., Davies, A., 2006. Children, place and identity: nation and locality in middle childhood. Routledge, London.

Short, G., 2012. As Falkland Islanders, we have the right to decide our own fate. The Guardian: comment is free. http://www.guardian.co.uk/commentisfree/2012/jun/13/falkland-islanders-right-decide-fate (last accessed 4 June 2013). 
Skelton, T., 2005. 'The Commonwealth Games baton arrives in Montserrat': symbols of children's 'citizenship' in a complex political setting. Children's Geographies 3, 363-367.

Skelton, T., 2010. Taking young people as political actors seriously: opening the borders of political geography. Area 42, 145-151.

Thrift, N., 2000. It's the little things. In: Dodds, K., Atkinson, D. (Eds.) Geopolitical Traditions: a century of geopolitical thought. Routledge, London, pp. 380-387.

vom Hau, M., 2009. Unpacking the school: textbooks, teachers, and the construction of nationhood in Mexico, Argentina, and Peru. Latin American Research Review 44, 127-154.

Webster, G., 2011. American nationalism, the flag, and the invasion of Iraq. Geographical Review 101, 118.

\section{Captions for figures}

Figure 1: Arts mural made by young people at the FICS for the $30^{\text {th }}$ anniversary of the Falklands war. Figure 2: Malvinas poster for secondary schools produced by the Argentine Ministry of Education. 